\title{
First record of Phytophthora drechsleri on Gynura formosana
}

\author{
Yi-Jia Lin ${ }^{1} \cdot$ Tung-Chin Huang ${ }^{1} \cdot$ Yu-Heng Lin ${ }^{1} \cdot$ Yuan-Min Shen ${ }^{1}$ (D)
}

Received: 15 March 2019 / Accepted: 19 May 2019 / Published online: 27 May 2019

(C) Australasian Plant Pathology Society Inc. 2019

\begin{abstract}
In October 2018, collar rots were observed on seedlings of Gynura formosana in Taiwan. The causal agent was identified as Phytophthora drechsleri based on the morphological and molecular characteristics. Pathogenicity tests demonstrated that the isolate is pathogenic to G. formosana and G. bicolor. To our knowledge, this is the first report of G. formosana as a host of P. drechsleri.
\end{abstract}

Keywords Phytophthora drechsleri $\cdot$ Oomycetes $\cdot$ Medicinal plant $\cdot$ Vegetables $\cdot$ DNA barcodes $\cdot$ Taiwan

Gynura formosana, known as bai-feng-cai, is a herbaceous plant belonging to the Compositae (Asteraceae) family that is native to Taiwan. It is consumed as a vegetable and as a folk medicine by Taiwanese indigenous tribes (Yang and Gao 2011) and in East Asia (Chen et al. 2003; Hou et al. 2005; Ma et al. 2017, 2018). The herb has been proved to possess antioxidant, anti-inflammatory, and potent anticancer activities (Chen et al. 2003; Hou et al. 2005; Lin et al. 2014; Ma et al. 2017, 2018).

There are some reports of Gynura diseases caused by various groups of pathogens such as viroids (Gross et al. 1982; García-Arenal et al. 1987), fungi, and oomycetes. The plant pathogenic fungi have been reported to cause rusts (Hiratsuka and Hashioka 1937), powdery mildew (Shen et al. 2015), anthracnose (Wehlburg et al. 1975), leaf spots (Wehlburg et al. 1975; Hsieh and Goh 1990; Nishikawa and Nakashima 2015), and root and stem rots (Wehlburg et al. 1975), whereas the Gynura-infecting oomycetes have caused downy mildew (Palmateer et al. 2015), Pythium root rots (Wehlburg et al. 1975), and Phytophthora blights (Shen et al. 2011). However, these studies do not mention any G. formosana diseases caused by the pathogens.

In October 2018, G. formosana and G. bicolor were cultivated under organic practices at the organic experimental farm (24.004934, 120.534028) of Taichung District Agricultural

Yuan-Min Shen

shenym@tdais.gov.tw

1 Taichung District Agricultural Research and Extension Station, Dacun, Changhua, Taiwan
Research and Extension Station (TCDARES) in Dacun, Changhua County, Taiwan. Two weeks after transplanting, wilt and collar rot symptoms were observed on G. formosana (Fig. 1) with an incidence of 9\% (300 plants surveyed) while 300 plants of G. bicolor investigated in the field were healthy. Brown to black lesions extending on the base of $G$. formosana seedlings became dried. Eventually, the plants were toppled and died. Symptomatic basal stems were collected, dissected, surface-sterilized for $10 \mathrm{~s}$ in $0.6 \%$ sodium hypochlorite solution, rinsed with sterilized water twice, dried on sterile paper tissues and plated on $2 \%$ water agar. White colonies with the same traits resembling Phytophthora were consistently isolated and the hyphal tips of one representative colony were further sub-cultured. The isolate was routinely transferred onto potato dextrose agar (PDA) and 5\% unclarified V8 vegetable juice agar (V8A). The colony growth patterns were rose-shaped and uniform (Safaiefarahani et al. 2015) on PDA and V8A, respectively (Fig. 2a).

To record the growth rates of the isolate under the temperatures between 28 and $40{ }^{\circ} \mathrm{C}$, Petri dishes $(9 \mathrm{~cm}$ diam. $)$ containing V8A were inoculated with mycelial plugs $(5 \mathrm{~mm}$ diam.) excised from the edge of a mycelial colony. The plugs were placed upside down in the center of each plate. After incubating in the dark for 3 and 5 days, the radius of each colony under various temperatures was measured in two perpendicular directions. Three replicates were measured for each temperature. The mean radial growth rates were $10.74,6.86$, 5.00 and $0.08 \mathrm{~mm} \mathrm{~d}^{-1}$ at $28,34,36$ and $38{ }^{\circ} \mathrm{C}$, respectively (the growth rate at $28{ }^{\circ} \mathrm{C}$ was calculated by data derived from 3 days of incubation, the other three were calculated by data derived from 5 days of incubation). No mycelial growth was observed at $40{ }^{\circ} \mathrm{C}$. 
Fig. 1 Symptoms in the field: a Bai-feng-cai ( $G$. formosana) grown in the organic experimental farm, black arrow indicates a diseased seedling. b Wilted seedling with brownish lesions on the dried basal stem
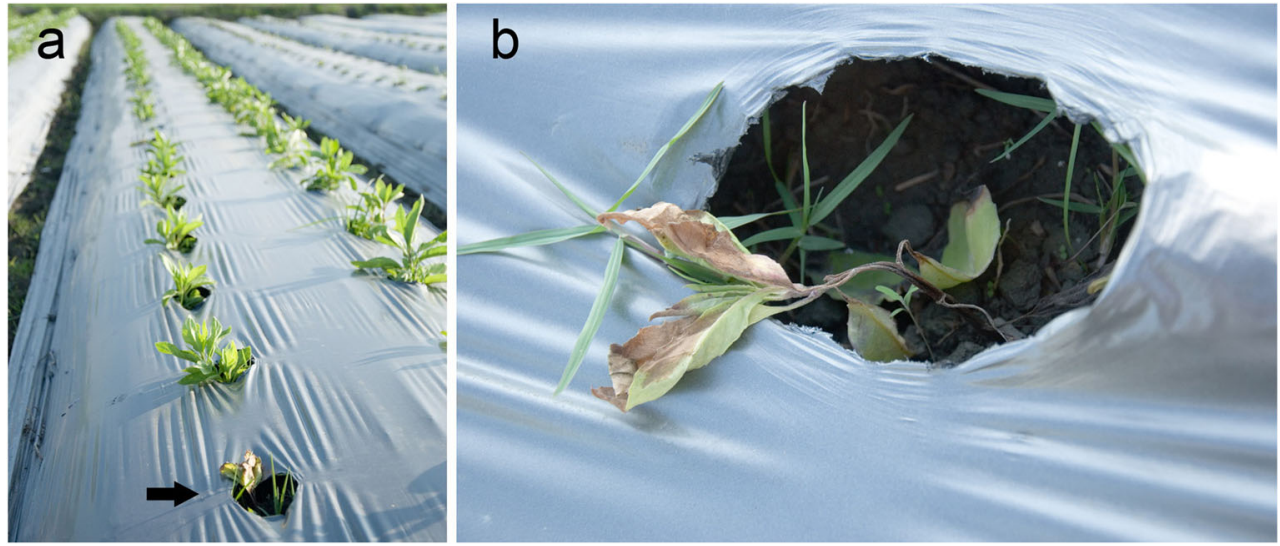

To induce sporangia production and characterize the isolate, the 8-day-old mycelia on V8A were flooded with sterile distilled water under $28^{\circ} \mathrm{C}$ for 5 days. The sporangia (Fig. 2b) were noncaducous, nonpapilate, ovoid to obpyriform in shape, with an average of $42.9 \mu \mathrm{m}$ in length and $27.3 \mu \mathrm{m}$ in width (ranges from 30.0-62.5 $\mu \mathrm{m}$ long and 20.0-30.0 $\mu \mathrm{m}$ wide; $n=30$ ). Hyphal swellings were present but oospores were absent. Oospores were formed in dual cultures with P. nicotianae 731 isolate (A2 mating type) (Ann 1996), suggesting that the present isolate belongs to a heterothalic, A1 mating type Phytophthora species.

Molecular comparisons were performed for species identification. The genomic DNA was extracted with a Taco Plant DNA/RNA Extraction Kit using Taco ${ }^{\mathrm{TM}}$ Nucleic Acid Automatic Extraction System (GeneReach Biotechnology, Taiwan) following the manufacturer's protocol. The internal transcribed spacer (ITS), cytochrome c oxidase subunit 1 (COX) gene fragment, $ß$-tubulin (TUB) gene fragment, NADH dehydrogenase subunit 1 (NADH1) gene fragment, heat shock protein 90 (HSP90) gene fragment, and a portion of the elicitin (ELI) gene were amplified using primer pairs ITS1/ITS4 (White et al. 1990), COXF4N/COXR4N, TUBUF2/TUBUR1, NADHF1/NADHR1 (Kroon et al. 2004), HSP90 F1 int/HSP90 R2 (Blair et al. 2008), and PEX1F/PEX1R (Mostowfizadeh-Ghalamfarsa et al. 2010), respectively. BLAST searches against the GenBank database showed that the sequences of the isolate had close identity with those of $P$. drechsleri Tucker ex-type materials (ATCC46724, CBS 292.35, CH 23J5, and SCRP232) (Kroon et al. 2004; Mostowfizadeh-Ghalamfarsa et al. 2010; Yang and Hong 2018): $99.9 \%$ for the ITS, $99.7 \%$ for the COX, $99.5 \%$ for the TUB, $100 \%$ for the NADH1, $99.9 \%$ for the HSP90, and $99.0 \%$ for the ELI sequences.

Based on the morphological and molecular characteristics, the Phytophthora derived from G. formosana is identified as $P$. drechsleri. Sequences of the isolate have been submitted to GenBank, accessions MK605947 (ITS), MK609543 (COX), MK609540 (TUB), MK609544 (NADH1), MK609541 (HSP90), and MK609542 (ELI). The isolate has been deposited in Bioresource Collection and Research Center, Taiwan, under the BCRC number $\mathrm{CH} 30305$.

Pathogenicity tests were conducted by inoculating P. drechsleri BCRC CH30305 on potted G. formosana seedlings in a greenhouse in TCDARES. Each of the seedlings (propagated from 8 to $10 \mathrm{~cm}$ stem cuttings, with more than 3 leaves) was grown in a 3-in. plastic nursery pot filled with Tref No. 003B horticultural substrate. Three dishes $(9 \mathrm{~cm}$ diam.) of the mycelia (8-day-old culture, flooded with sterile distilled water for another 2 days) on V8A were scraped, mixed with an additional $10 \mathrm{~g}$ of the substrate, and evenly placed at the base of 3 potted plants on the day of propagation. Three plants treated with sterile V8A processed in the same way served as controls. The inoculated and control seedlings were separately placed into a closed transparent plastic box
Fig. 2 Phytophthora drechsleri BCRC CH30305 isolate a Colonies grown on PDA (left) and V8A (right) in 9-cm Petri dishes for 12 days under $28^{\circ} \mathrm{C}$ in the dark. b A sporangium
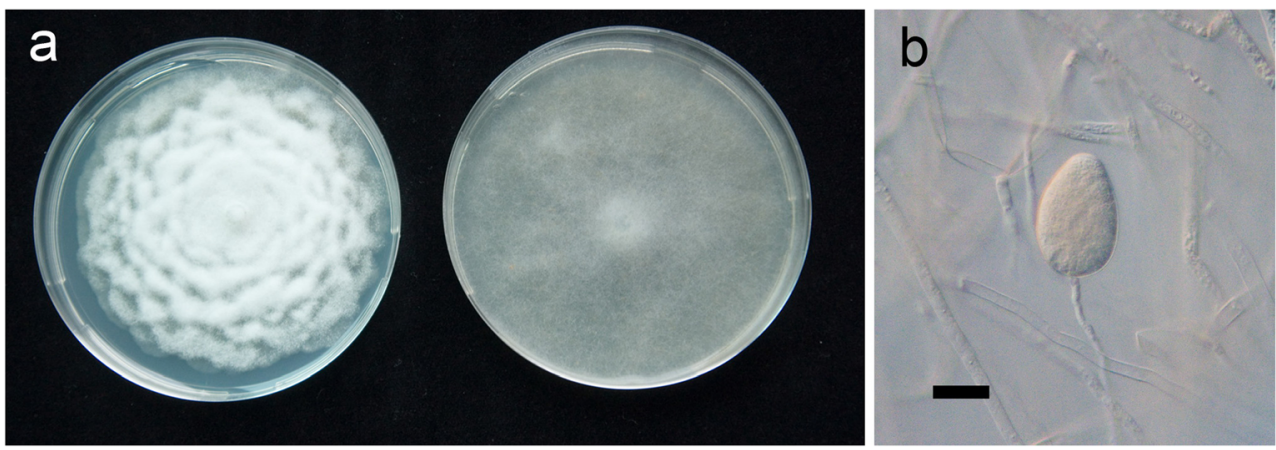
and the lid was opened 2 days post inoculation (dpi). Initial symptoms began 5 dpi and all inoculated seedlings showed collar rot and leaf blight 1 week after inoculation (Fig. 3). At the end of the trial ( 2 weeks), the brownish lesions had extended and the whole plants were deteriorated. The controls remained symptomless. The average temperature was $21.2^{\circ} \mathrm{C}$ during the time periods. The pathogen reisolated from the edge of the lesion was identified as $P$. drechsleri based on the morphological and ITS sequence characteristics, fulfilling Koch's postulates. The pathogenicity test was again performed by inoculated the pathogen on G. formosana and G. bicolor seedlings with approximately the same procedures. All the inoculated plants were symptomatic at 8 dpi while the control plants remained healthy. In the same way, the pathogen was successfully reisolated from artificially inoculated G. formosana and G. bicolor diseased tissues. The result indicated that the $P$. drechsleri isolated from diseased G. formosana was also pathogenic to G. bicolor.

This study reports the first occurrence of a Phytophthora disease on G. formosana in Taiwan. It is demonstrated that the isolated $P$. drechsleri is virulent towards both G. formosana and G. bicolor. Probably the healthiness conditions of the vegetative propagation materials can give rise to different levels of the disease infection between the two plant species at the early growing stage since the pathogen is able to be introduced through the movement of seedlings (Lamour et al. 2003) or nonsymptomatic plants (Olson and Benson 2013). Phytophthora drechsleri, a worldwide distributed pathogen with over 200 reported hosts in 113 genera of 40 plant families (Farr and Rossman 2019), could be specific or nonspecific to the host plants (Olson and Benson 2013). The pathogen can affect different plant parts and may be aggressive to Gynura (Shen et al. 2011) and various economic crops (Olson and Benson 2013; Sosa et al. 2015; Farr and Rossman 2019) under favorable conditions for the disease development. To our knowledge, this is the first record of G. formosana as a host of $P$. drechsleri.

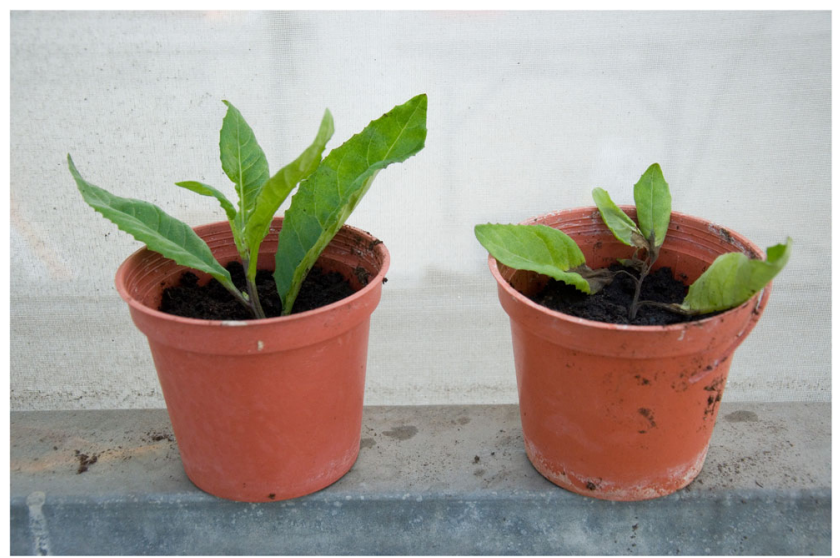

Fig. 3 A pathogenicity test result at 8 dpi: healthy control plant (left) and inoculated plant (right)
Acknowledgements We thank He, Mei-Ling (TCDARES) for the assistance of laboratory works. We also thank Lin, Chu-Ping and Ann, PaoJen (Taiwan Agricultural Research Institute) for providing the P. nicotianae isolate.

\section{References}

Ann PJ (1996) Phytophthora diseases of Compositae in Taiwan. Plant Pathol Bull 5:146-153

Blair JE, Coffey MD, Park SY, Geiser DM, Kang S (2008) A multi-locus phylogeny for Phytophthora utilizing markers derived from complete genome sequences. Fungal Genet Biol 45:266-277. https://doi. org/10.1016/j.fgb.2007.10.010

Chen SC, Hong LL, Chang CY, Chen CJ, Hsu MH, Huang YC, Huang TH, Kuo SC (2003) Antiproliferative constituents from Gynura divaricata subsp. formosana. Chin Pharm J 55:109-119. https:// doi.org/10.7019/CPJ.200304.0109

Farr DF, Rossman AY (2019) Fungal databases, U.S. National Fungus Collections, ARS, USDA. https://nt.ars-grin.gov/fungaldatabases/. Accessed 13 May 2019

García-Arenal F, Pallás V, Flores R (1987) The sequence of a viroid from grapevine closely related to severe isolates of citrus exocortis viroid. Nucleic Acids Res 15(10):4203-4210

Gross HJ, Krupp G, Domdey H, Raba M, Jank P, Lossow C, Alberty H, Ramm K, Sänger HL (1982) Nucleotide sequence and secondary structure of citrus exocortis and chrysanthemum stunt viroid. Eur J Biochem 121(2):249-257

Hiratsuka N, Hashioka Y (1937) Uredinales collected in Formosa. VI. Bot Mag 51(602):41-47. https://doi.org/10.15281/jplantres1887.51. 41

Hou WC, Lin RD, Lee TH, Huang YH, Hsu FL, Lee MH (2005) The phenolic constituents and free radical scavenging activities of Gynura formosana Kiamnra. J Sci Food Agric 85:615-621. https://doi.org/10.1002/jsfa.2017

Hsieh WH, Goh TK (1990) Cercospora and similar fungi from Taiwan. Maw Chang Book Co., Taipei

Kroon LPNM, Bakker FT, van den Bosch GBM, Bonants PJM, Flier WG (2004) Phylogenetic analysis of Phytophthora species based on mitochondrial and nuclear DNA sequences. Fungal Genet Biol 41: 766-782. https://doi.org/10.1016/j.fgb.2004.03.007

Lamour KH, Daughtrey ML, Benson DM, Hwang J, Hausbeck MK (2003) Etiology of Phytophthora drechsleri and P. nicotianae (=P. parasitica) diseases affecting floriculture crops. Plant Dis 87 : 854-858. https://doi.org/10.1094/PDIS.2003.87.7.854

Lin KH, Yah H, Lin SY, Yang CM, Tsai HJ, Tsai JJ, Chao PY (2014) Antioxidant activities of methanol extracts from selected Taiwanese herbaceous plants. J Food Nutr Res 2(8):435-442. https://doi.org/ $10.12691 / j \mathrm{jnn}-2-8-2$

Ma J, Guo C, Pan Y, Lin D, Qiu L, Wen L (2017) Antioxidant and antiinflammatory activities of ethyl acetate extract of Gynura formosana (Kitam) leaves. Exp Ther Med 14:2303-2309. https://doi.org/10. 3892/etm.2017.4757

Ma JF, Wei PF, Guo C, Shi YP, Lv Y, Qiu LX, Wen LP (2018) The ethyl acetate extract of Gynura formosana Kitam. leaves inhibited cervical cancer cell proliferation via induction of autophagy. Biomed Res Int 2018:4780612. https://doi.org/10.1155/2018/4780612

Mostowfizadeh-Ghalamfarsa R, Panabieres F, Banihashemi Z, Cooke DEL (2010) Phylogenetic relationship of Phytophthora cryptogea Pethybr. \& Laff and P. drechsleri Tucker. Fungal Biol 114:325-339. https://doi.org/10.1016/j.funbio.2010.02.001

Nishikawa J, Nakashima C (2015) Morphological variation and experimental host range of Alternaria cinerariae. Mycoscience 56:141149. https://doi.org/10.1016/j.myc.2014.05.001 
Olson HA, Benson DM (2013) Host specificity and variations in aggressiveness of North Carolina isolates of Phytophthora cryptogea and P. drechsleri in greenhouse ornamental plants. Plant Dis 97:74-80. https://doi.org/10.1094/PDIS-02-12-0170-RE

Palmateer AJ, Cating RA, Lopez P (2015) First report of downy mildew on Gynura aurantiaca caused by Plasmopara halstedii sensu lato in Florida. Plant Dis 99:1279. https://doi.org/10.1094/PDIS-11-141166-PDN

Safaiefarahani B, Mostowfizadeh-Ghalamfarsa R, Hardy GESJ, Burgess TI (2015) Re-evaluation of the Phytophthora cryptogea species complex and the description of a new species, Phytophthora pseudocryptogea sp. nov. Mycol Prog 14:108. https://doi.org/10. 1007/s11557-015-1129-9

Shen YM, Chao CH, Liu HL (2011) First report of Phytophthora drechsleri associated with stem and foliar blight of Gynura bicolor in Taiwan. Plant Dis 95:874. https://doi.org/10.1094/PDIS-12-100931

Shen YM, Huang TC, Liu HL, Chao CH (2015) First report of the powdery mildew Podosphaera xanthii on Gynura bicolor. Aust Plant Dis Notes 10:27. https://doi.org/10.1007/s13314-015-0177-y
Sosa MC, Lutz MC, Vélez ML, Greslebin A (2015) Pre-harvest rot of pear fruit Golden russet bosc caused by Phytophthora lacustris and Phytophthora drechsleri in Argentina. Aust Plant Dis Notes 10:18. https://doi.org/10.1007/s13314-015-0169-y

Wehlburg C, Alfieri SA, Langdon KR, Kimbrough JW (1975) Index of plant diseases in Florida. Florida Department of Agriculture and Consumer Services, Gainesville

White TJ, Bruns TD, Lee S, Taylor JW (1990) Amplification and direct sequencing of fungal ribosomal RNA genes for phylogenetics. In: Innis MA, Gelfand DH, Sninsky JJ, White TJ (eds) PCR protocols: a guide to methods and applications. Academic Press, Inc., San Diego, pp 315-322

Yang SZ, Gao YJ (2011) A preliminary study on diverse plant uses of Rukai tribe in Wutai district of Pingtung County, southern Taiwan. Taiwania 56(1):7-16. https://doi.org/10.6165/tai.2011. $56(1) .7$

Yang X, Hong C (2018) Differential usefulness of nine commonly used genetic markers for identifying Phytophthora species. Front Microbiol 9:2334. https://doi.org/10.3389/fmicb.2018. 02334 